\title{
Issue Of Social Exclusion In India: Perspectives And Challenges
}

\author{
Dr. Sandipan R. Gavhale \\ Assistant Professor in Economics Annasaheb Waghire College Otur, Junnar, Pune 412409. \\ Affiliated to Savitribai Phule Pune University, Maharashtra, India.
}

\begin{abstract}
"Indifferentism is the worst kind of disease that can affect people" Dr. Babasaheb Ambedkar
Abstract:-India is a caste base social system, therefore, Indian society suffers from substantial inequalities in education, employment, and income based on caste and ethnicity that means caste as a system of exclusion and exploitation. In the identification of the poor, scheduled caste and scheduled tribes and in some cases the other backwards castes are considered as socially disadvantaged groups and such groups have a higher probability of living under adverse conditions and poverty. So this study generally points out that socioeconomic status of exclusion social groups in India. This ground reality raises a number of questions. What is the impact of the policy of positive discrimination in terms of employment, education and political empowerment of excluded social groups in India? Do positive discriminations help in the elimination of social stigma? The Constitution of India has taken special care for exclusion and uplifts certain marginalised communities in India.
\end{abstract}

Key Notes:-Social exclusion, Marginalization, Determinants, Inequality, Exploitation, The role of religions in poverty eradication,

\section{INTRODUCTION}

Today's, people need to the guaranty of income sources as well as social security, that both should be provided by the government, but, this measuring thing has been deliberately ignored by the government, which are happening cause of less political desire. So the economic disparities in society have not been eradicated by the government. Recently, the political equality issue has been raised by the political parties until completion an election period, but today's no one party is ready to discuss the point of social and economic equality. It means today's also exist the economic disparity than that of social. This condition exists in both communities (SC, ST), which people were socially excluded since before the time, but today they have become an economically excluded due to the socioeconomic disparity.

Indian constitution having a special provision for SC and ST, but after independence, it has not been affected? Properly by the government, so this person living as a poverty life. It illustrates that the measurable goal of creating the democratic society has not come in truth. Consequently, in this paper having a try to focus on the socio-economic problems of SC and ST after independence. So free from this problematic situation we want to eradicate the discriminating policy in society. However, nowadays some religious and communal pride, power making the best effort to be remained permanently racism in India. For example, if we have seen the reservation fact of the Indian constitution was executed from 1950, but in view of education and employment reservation for Scheduled Caste and Scheduled Tribe having started from in fact during the period of 1960-65, in the starting period (1950) this child was into $1^{\text {st }}$ standard, which rich in 10 standards in 1960 , and then some children reach in graduation in 1965, among them some have got the class three and class four posts such like a peon and clerk. In overall, today have not confirmed that $100 \%$ reservation to be SC and ST has been executed by the government during 1960-65 to 2015. This problematic situation has not been properly discussed by the government as well, have not the proper answer that why this is happening. Today's also these people living in poor condition, for instance, they have no good education, employment and business, in overall the government has a failure to be destroyed the socio-economic disparities in society.

\section{THEORY OR BACKGROUND OF STUDY}

The Role of Religion in the Struggle against Poverty diverts, as stated by Karl Marx, which country is suffering from poverty, their people always diverted at the fascists from that fundamental right through the basis of religion, such like the fascist increases constantly. So to improve in poverty situation should not be used by religion in India. Poverty does not consist only in a low economic status. It means hunger, disease, illiteracy, lack of shelter and privacy. It implies exclusion, discrimination, powerlessness, a feeling inferiority and sense of hopelessness. It is struggling for survival, being enslaved to seeking a crumb. It is criminal because it does not 
allow people to be people. It is a scar on our face; it is a denial of human rights and the gravest insult to human dignity.

Poverty in India cannot be interpreted totally as the result of underdeveloped technology and overpopulation, nor can struggle against it seem totally as a matter of economic growth. The point is that poverty is not primarily of underdevelopment but of an economic power structure, who share the values of affluence and consumerism the power deciding the direction of utilization of limited available technology, raw materials and energy and who therefore exploit the people. In the early period of the British rule, the economy was a balanced integration between village industry and agriculture in a "Need-based" structure, the kind of naked poverty and unemployment that we see today was not there. However, this need-based economy was destroyed and a modern "Want-based" economy was landed, industrial and commercial aristocracy exploiting the people. High concentration of economic power, which is potential for growth, is the source of mass poverty. One of the most disquieting features is the internal domination-dependence relationship, a kind of domestic imperialism. Any amount of sources, whether internal or external, injected into such a system tends to strengthen prevailing non-egalitarian institutions, intensifying exploitation and aggravating the misery of the poor. The introduction of resources increases wealth but ends up by aggravating the poverty of the masses. Therefore, there is no simple solution to poverty through more of it.

\section{OBJECTIVE}

1. To Study the current socio-economic condition of Scheduled Caste and Scheduled Tribe in Indian caste system after that independence.

2. To suggest the proper measurement for the betterment of Scheduled Caste and Scheduled Tribe.

\section{HYPOTHESIS}

Till today, the Indian caste system is responsible for the backwardness or the socio-economic exclusion of SC and ST groups.

\section{RESEARCH METHODOLOGY}

The research methodology is based on the relevant secondary data.

Coverage: The study, confines to a concept of inequality in Indian society and socially excluded groups in development.

\section{Relevant Argument Of The Study}

The scholar thought of an economic system and the structure of social change as well as;

The economic equality in India, will not be established until then there exists of a caste-based economy. With this connection, there has been incorporated some reviews of socio-economic research, as well, some outlook of expert in reference with 'economic system and structure for social change' are very important, which are;

Every individual and society has to satisfy certain physical and psychological needs such as Food, Clothing, Shelter, Art, Entertainment, Medicines, Ceremonies, etc. They meet this need through the instruments of labour and every society possesses an economic organization or system. There are two approaches to economics, namely the Capitalist and Socialist or Marxist.

Paul A. Samuelson has defined the economic system is comprised of four basic structures such as production (productive force, means of production, labour), distribution, exchange and consumption (technical relations or organization and social relations). The capitalism brought great transformation by suppurating economic function from the social relations. The bifurcation of people based on family, caste, ethnic grouping, religious community, urban-rural division are playing the basic role assigning people their place, task, claim on resources and status in the society. Economic transactions increasingly dominate all areas of life, which is described as monetization, marketization, and commoditization.

M. M. Thomas Approach, economic exploitation, social oppression and religious fatalism are prevalent. Poverty and capitalism are the root cause of the economic inequality in the society. Human beings need freedom from all kinds of slavery. Women and children are looked inhuman and are deprived as well as go through sexual harassment. The concerns for social justice and new economic values have to be introduced into the framework. There is a lack of participation of all sectors of society in the decision-making structures of the economic organization of all stage planning, execution, and evaluation.

Paulose Mar Paulose says economic injustice requires economic equality. The Marxism fight against economic injustice influenced him. He opposes the popular view of religion that economic backwardness in one's fate and prosperity is the blessing of God. According to the Biblical understanding, he says, a human 
being has only 'the stewardship' of the earth. In God's economic plan, all human beings are supposed to be the equal and equal distribution of resources. To eradicate poverty, people should not be considered merely as the objects of the charity, but they should be encouraged to become the agents to change the unjust economic structure and economic oppression. The proletarians should have the right to get an equal share of profit.

Karl Marx the atheistic critic of religion points at some of the deep longings, which express themselves in religion, when he writes, "Religious distress is at the same time the expression of real distress and also the protest against real distress. Religion is the sigh of the oppressed creature, the heart of a heartless world, just as it is the spirit of the spiritless conditions, but he continues it is the opium of the people."

Max Weber is founders of modern sociology, he also accomplished much in other fields, notably economics dealing with the structure of Indian society were from the ancient day's social system were shaped by the concept of caste. Max Weber tried to identify the contribution of ascetic puritan ethic rooted in Calvinist faith in the building of a tremendous cosmos of the modern economic order, which determines the lives of all individuals born into it with irresistible force. Weber points at the illusions of modern society, which has lost the spirit of religion.

Emil Durkheim the French founding figure of sociology stated that society without a religious expression of its sense of purpose and coherence would not be sustainable. This influenced the young Dr. Ambedker in pursuing his search for a proper religious foundation for an egalitarian, caste-free and fraternal society in India. Weber treated religion as a key variable in understanding how society works. These and other classical theorists would have had difficulty conceptualizing a society in which religion did not play a major role, and they sought to understand that role. Popular conceptions of the time also attributed an important place in the culture of societies to religion, and this contributed to the attention paid to religion by early theorists. Durkheim believed that religion was a major factor leading to social solidarity, integration, and cohesion. Max Weber formulated a three-component theory of stratification, with Social class, Social status and party (political) as conceptually distinct elements.

\section{DISCUSSION}

Indian society, particularly Hindu religion, is of feudal mind set. It is caste oriented the lower castes are Depressed communities and backwards, and the so-called upper-caste are Brahmin, Bania and Rajput. Out of 1,250 million ( 125 crores) population of India as of 2011, 1,000 million (100 crores) belong to the lower castes and 250 million ( 25 crores) to the so-called upper-caste. Thus, $20 \%$ people have been socially ruling over the $80 \%$ people. Lower caste people have been deprived of better-earning professions in rural areas. The $90 \%$ of the lower caste people are poor and live under inhuman conditions. They have been denied of Education, Healthcare and Employment, the dignity of life and profession.

Thus, they lack education, bank account and identity documents. The $90 \%$ of the lower caste people is the most benefited of Aadhar, the national identification number. It is so because they do not possess the education and other identity documents, and have been living the faceless, nameless and socially excluded life of destitute, generation by generation, in the own nation for centuries despite the same colour skin and same religion. These 1 billion exploited people are mainly victims of socio-economic inequalities such as caste-based wealth distribution, caste based land distribution, housing, education, caste-based profession, caste-based marriages, caste-based social life etc.

\section{Literature Review}

1. Ruth Levitas, Christina Pantazis, Eldin Fahmy, David Gordon, Eva Lloyd and Demi Patsios (2007), "The Multi-Dimensional Analysis Of Social Exclusion", states in this article, which the multi-dimensional analyses of social exclusion. The underlying statistical framework is a sub-system variables approach in which social indicators are recognized as output and input measures which can be used to judge 'progress' towards the social goal of inclusion. A causal model is implicit in this work that will facilitate the identification of policy interventions that will reduce exclusion.

2. Satyajit Das (2014), "Reservation and National Integration in India: An Evaluative Description", in his study represent the most important feature of the social structure in India is the caste system. Due to this, the Indian society is divided into so many class, community and clans such as scheduled caste, scheduled tribe and other weaker sections of Indian society. The present study intends to narrate the provisions enshrined in Indian constitution for the above-mentioned people and the paper also emphasis on the impact of reservation on national integration in India.

3. Dr. Ambedkar Vision of Social Justice, For The Women, Scheduled Castes And Scheduled Tribes, they defines the opinion about social justice that 'Social justice has significance in the context of Indian society 
which is divided into Castes and Communities and they create walls and barriers of exclusiveness on the basis of superiority and inferiority such inequalities pose serious threat to Indian democracy. The concept of social justice takes within its sweep the objective of removing inequalities and affording equal opportunities to all citizens in social, economic and political affairs'.

4. In the $11^{\text {th }}$ five-year plan chapter six Social Justice Scheduled Castes, Scheduled Tribes, Other Backward Classes, Minorities, and Other Vulnerable Groups, represent inclusive growth demands that all social groups have equal access to the services provided by the state and equal opportunity for upward economic and social mobility. It is also necessary to ensure that there is no discrimination against any section of our society.

\section{Subject}

\section{Definition of Social exclusion}

- Social exclusion or marginalization is a social disadvantage and relegated to the fringe of society. It is a term used widely in the United Kingdom, Europe and was first used in France. It is used across disciplines including Education, Sociology, Psychology, Politics and Economics.

- Social exclusion is the process in which individuals or entire communities of people are systematically blocked from rights, opportunities and resources (e.g. housing, employment, healthcare, civic engagement, democratic participation and due process) that are normally available to members of society and which are key to social integration.

- Social exclusion is a broader concept than poverty, encompassing not only low material means but the inability to participate effectively in economic, social, political and cultural life and in some characterizations alienation and distance from mainstream society. (Duffy, 1995)

\section{The Socio-economic Review of SC, ST and Other Social groups in India}

The present article basically focuses on the characteristic of SC and ST Population and their Education, Health, Poverty and Employment, etc. which illustrate that this person has been displaced by the development, as well it seems that they have not as much of means of income consequently they have been living in poor condition.

Table 1: Educational Attainment and Transition Probabilities at Various Educational Levels (Survey Year 1999-2000, NSS 55th round)

\begin{tabular}{|c|c|c|}
\hline & $\begin{array}{l}\text { Educational } \\
\text { Attainment }\end{array}$ & $\begin{array}{l}\text { Transition } \\
\text { Probability }\end{array}$ \\
\hline \multicolumn{3}{|c|}{ Upper Caste Hindu \& Other Religion } \\
\hline Illiterate \& Below Primary & 30.40 & \\
\hline Primary & 17.45 & 0.70 \\
\hline Middle & 23.88 & 0.82 \\
\hline Secondary & 22.82 & 0.66 \\
\hline College & 5.45 & 0.34 \\
\hline \multicolumn{3}{|l|}{100.00} \\
\hline \multicolumn{3}{|l|}{ Scheduled Class } \\
\hline Illiterate \& Below Primary & 50.45 & \\
\hline Primary & 17.88 & 0.50 \\
\hline Middle & 18.49 & 0.71 \\
\hline Secondary & 11.61 & 0.52 \\
\hline College & 1.57 & 0.22 \\
\hline \multicolumn{3}{|l|}{100.00} \\
\hline \multicolumn{3}{|l|}{ Scheduled Tribe } \\
\hline Illiterate \& Below Primary & 57.29 & \\
\hline Primary & 15.08 & 0.43 \\
\hline Middle & 16.58 & 0.72 \\
\hline Secondary & 9.57 & 0.52 \\
\hline College & 1.48 & 0.25 \\
\hline \multicolumn{3}{|l|}{100.00} \\
\hline \multicolumn{3}{|l|}{ Muslim } \\
\hline Illiterate \& Below Primary & 48.05 & \\
\hline Primary & 17.95 & 0.52 \\
\hline Middle & 19.53 & 0.71 \\
\hline
\end{tabular}




\begin{tabular}{|l|l|l|}
\hline Secondary & 12.56 & 0.52 \\
\hline College & 1.91 & 0.25 \\
\hline 100.00 & \multicolumn{2}{|l|}{} \\
\hline
\end{tabular}

Source: India Human Development Survey Working Paper No. 6

* Only people who completed the previous level and are of appropriate age at included in calculating transition Probabilities.

Table No. 1indicateseducational attainment and transition probabilities at various educational levels of Upper caste \& other religion, Scheduled Class, Adivasi (ST), and Muslim people. This picture shows that educational backwardness among the SC, ST, and Muslim compared to Upper caste and other religions.But, the population growth rate of these tribes also is lower than an average growth rate of total general population and this class literacy rate is lower than general ratio 74.04\% as anSC-66.10\% and ST-58.96\% (Census 2011).

Table 2: Numbers and Area of Operational Holdings amongst SC, ST, \& Others in India

(Number \& Area in thousand hectares2005-06)

\begin{tabular}{|c|c|c|c|c|c|c|c|c|c|c|c|c|c|c|}
\hline \multirow{2}{*}{$\begin{array}{l}\text { Category } \\
\text { of } \\
\text { Holdings }\end{array}$} & \multicolumn{4}{|l|}{ SC } & \multicolumn{4}{|l|}{ ST } & \multicolumn{4}{|l|}{ Other } & \multicolumn{2}{|l|}{ All } \\
\hline & Number & $\begin{array}{l}\% \\
\text { All }\end{array}$ & Area & $\begin{array}{l}\% \\
\text { All }\end{array}$ & Number & $\%$ All & Area & $\%$ All & Number & $\begin{array}{l}\% \\
\text { All }\end{array}$ & Area & $\begin{array}{l}\% \\
\text { All }\end{array}$ & Number & Area \\
\hline Marginal & $\begin{array}{l}12233.44 \\
(76.11)\end{array}$ & 14.62 & $\begin{array}{l}4493.94 \\
(33.79)\end{array}$ & 14.03 & $\begin{array}{l}4586.16 \\
(49.08)\end{array}$ & 5.48 & $\begin{array}{l}2221.51 \\
(14.35)\end{array}$ & 6.93 & $\begin{array}{l}66874.77 \\
(64.42)\end{array}$ & 79.90 & $\begin{array}{l}25310.52 \\
(19.54)\end{array}$ & 79.03 & $\begin{array}{l}83694.37 \\
(64.77)\end{array}$ & $\begin{array}{l}32025.97 \\
(20.23)\end{array}$ \\
\hline Small & $\begin{array}{l}2445.14 \\
(15.21)\end{array}$ & 10.22 & $\begin{array}{l}3364.38 \\
(25.30)\end{array}$ & 10.16 & $\begin{array}{l}2400.31 \\
(25.69)\end{array}$ & 10.03 & $\begin{array}{l}3345.80 \\
(21.61)\end{array}$ & 10.11 & $\begin{array}{l}19084.18 \\
(18.38)\end{array}$ & 79.75 & $\begin{array}{l}26390.61 \\
(20.37)\end{array}$ & 79.73 & $\begin{array}{l}23929.63 \\
(18.52)\end{array}$ & $\begin{array}{l}33100.79 \\
(20.91)\end{array}$ \\
\hline $\begin{array}{l}\text { Semi- } \\
\text { medium }\end{array}$ & $\begin{array}{l}1013.52 \\
(6.31)\end{array}$ & 7.17 & $\begin{array}{l}2693.45 \\
(20.25)\end{array}$ & 7.11 & $\begin{array}{l}1550.05 \\
(16.59)\end{array}$ & 10.97 & $\begin{array}{l}4145.78 \\
(26.77)\end{array}$ & 10.94 & $\begin{array}{l}11563.55 \\
(11.14)\end{array}$ & 81.85 & $\begin{array}{l}31058.46 \\
(23.98)\end{array}$ & 81.95 & $\begin{array}{l}14127.12 \\
(10.93)\end{array}$ & $\begin{array}{l}37897.69 \\
(23.94)\end{array}$ \\
\hline Medium & $\begin{array}{l}325.83 \\
(2.03)\end{array}$ & 5.11 & $\begin{array}{l}1865.24 \\
(14.02)\end{array}$ & 5.10 & $\begin{array}{l}704.03 \\
(7.53) \\
\end{array}$ & 11.04 & $\begin{array}{l}4059.72 \\
(26.22)\end{array}$ & 11.10 & $\begin{array}{l}5345.48 \\
(5.15)\end{array}$ & 83.85 & $\begin{array}{l}30658.44 \\
(23.67)\end{array}$ & 83.80 & $\begin{array}{l}6375.34 \\
(4.93)\end{array}$ & $\begin{array}{l}36583.40 \\
(23.11)\end{array}$ \\
\hline Large & $\begin{array}{l}55.54 \\
(0.35)\end{array}$ & 5.07 & $\begin{array}{l}883.39 \\
(6.64)\end{array}$ & 4.72 & $\begin{array}{l}104.50 \\
(1.12)\end{array}$ & 9.54 & $\begin{array}{l}1713.12 \\
(11.06)\end{array}$ & 9.15 & $\begin{array}{l}935.74 \\
(0.90)\end{array}$ & 85.39 & $\begin{array}{l}16118.62 \\
(12.44)\end{array}$ & 86.13 & $\begin{array}{l}1095.78 \\
(0.85)\end{array}$ & $\begin{array}{l}18715.13 \\
(11.82)\end{array}$ \\
\hline $\begin{array}{l}\text { All size } \\
\text { classes }\end{array}$ & $\begin{array}{l}16073.47 \\
(100.0)\end{array}$ & 12.44 & $\begin{array}{l}13300.40 \\
(100.0)\end{array}$ & 8.40 & $\begin{array}{l}9345.05 \\
(100.0)\end{array}$ & 7.23 & $\begin{array}{l}15485.92 \\
(100.0)\end{array}$ & 9.78 & $\begin{array}{l}103803.72 \\
(100.0)\end{array}$ & $\begin{array}{r}80.33 \\
(100.0)\end{array}$ & $\begin{array}{l}129536.66 \\
(100.0)\end{array}$ & 81.82 & $\begin{array}{l}129222.24 \\
(100.0)\end{array}$ & $\begin{array}{l}158322.98 \\
(100.0)\end{array}$ \\
\hline
\end{tabular}

Source: $\underline{\text { http://agcensus.dacnet.nic.in }}$

Note: Other social Group Numbers and Area of Operational Holding are calculated by author.

Table no.2 shows the information about land holding proportion of SC, ST and Others social group, there are marginal, small, semi-medium, medium and large type of landholders, in which, the $12.44 \%$ landholders holding at $8.40 \%$ area out of the total land in India, $7.23 \%$ of ST holding $9.78 \%$ area, if $80.33 \%$ of other social group holding $81.82 \%$ area of land holding. Overall, $19.67 \%$ SC and ST social group people are holding only $18.18 \%$ land area, which shows the higher inequalities between two groups.

Table 3: Occupational qualification of main workers among SC/ST \& General Population.(1961 to 2011)

\begin{tabular}{|l|l|l|l|l|l|l|}
\hline Agricultural Labour & $\mathbf{1 9 6 1}$ & $\mathbf{1 9 7 1}$ & $\mathbf{1 9 8 1}$ & $\mathbf{1 9 9 1}$ & $\mathbf{2 0 0 1}$ & $\mathbf{2 0 1 1}$ \\
\hline General & 16.71 & 26.32 & 26.16 & 19.66 & 26.5 & 30.0 \\
\hline SC & 34.48 & 51.74 & 48.22 & 49.06 & 45.6 & 45.9 \\
\hline ST & 19.71 & 33.04 & 32.67 & 32.69 & 36.9 & 44.5 \\
\hline $\begin{array}{l}\text { Household } \\
\text { Industries }\end{array}$ & $\mathbf{1 9 6 1}$ & $\mathbf{1 9 7 1}$ & $\mathbf{1 9 8 1}$ & $\mathbf{1 9 9 1}$ & $\mathbf{2 0 0 1}$ & $\mathbf{2 0 1 1}$ \\
\hline General & 6.38 & 3.55 & 3.99 & 2.56 & 4.2 & 3.8 \\
\hline SC & 6.56 & 3.33 & 3.31 & 2.41 & 3.9 & 3.2 \\
\hline ST & 2.47 & 1.03 & 1.42 & 1.04 & 2.1 & 1.8 \\
\hline Other Workers & $\mathbf{1 9 6 1}$ & $\mathbf{1 9 7 1}$ & $\mathbf{1 9 8 1}$ & $\mathbf{1 9 9 1}$ & $\mathbf{2 0 0 1}$ & $\mathbf{2 0 1 1}$ \\
\hline General & 24.13 & 26.32 & 29.32 & 38.04 & 37.6 & 41.6 \\
\hline SC & 21.20 & 17.06 & 20.30 & 23.08 & 30.5 & 36.1 \\
\hline ST & 9.64 & 8.64 & 11.84 & 11.67 & 16.3 & 19.2 \\
\hline
\end{tabular}

Source: Indian Vision 2020 Report of the committee on India, Planning Commission GOI. Delhi. Primary Census Abstract for Total population, Scheduled Castes and Scheduled Tribes, Census 2011. 
Table No.3, this shows the figure about occupational qualifications of main workers means agricultural labour, household industries, and other worker population ratio of SC, ST, in 1961 to 2011. It defines that SC's agriculture, labour ratio was at $34.48 \%$, which increased to $45.9 \%$ in 2011 , it increased by $11.39 \%$ in during the period. As well, the ST's ratio was $19.17 \%$ in the previous period, and then it stood at $44.5 \%$ which was increased by $25.66 \%$ in after during the period (1961 to 2011). As well as, the SC's ratio in household industries was at $6.56 \%$ in 1961, which was less at 3.2\%, it decreased by $3.54 \%$ for the duration of the period. As well, this ratio of ST in previous period was at $2.47 \%$ which was the after period at $1.8 \%$, it decreased by $1.39 \%$,respectively.

Table 4: Percentage of SC/ST and all India populations below poverty line (During 1977-78 to 2009-2010)

\begin{tabular}{|c|c|c|c|c|c|c|c|c|c|c|c|}
\hline \multicolumn{4}{|c|}{ Scheduled Caste } & \multicolumn{4}{|c|}{ Scheduled Tribes } & \multicolumn{4}{|c|}{ All India } \\
\hline \multicolumn{2}{|c|}{$1977-78$} & \multicolumn{2}{|c|}{$2009-10$} & \multicolumn{2}{|c|}{$1977-78$} & \multicolumn{2}{|c|}{$2009-10$} & \multicolumn{2}{|c|}{$1977-78$} & \multicolumn{2}{|c|}{$2009-10$} \\
\hline Rural & Urban & Rural & Urban & Rural & Urban & Rural & Urban & Rural & Urban & Rural & Urban \\
\hline 64.6 & 54.3 & 43.5 & 33 & 72.4 & 52.6 & 47.1 & 28.8 & 51.2 & 38.2 & 33.8 & 20.9 \\
\hline
\end{tabular}

Source: Indian Vision 2020 Report of the committee on India, Planning Commission GOI. Planning Commission, Eleventh Five Year Plan, 2007-2012, Volume I, Inclusive Growth and NSSO primary data 2009- 10.

Table no. 4, which indicates the information about the poverty ratio of SC, ST and total population of India in 1977 to 2009, this period was near 32 years, in which, the SC's poverty ratio in Rural and Urban area, remained near $64.6 \%$ and $54.3 \%$, which was decreased by $21.1 \%$ and $21.3 \%$ in both areas and stood at $43.5 \%$ and $33 \%$, respectively. As well the same ratio of ST in the rural and urban area was also decreased by $25.3 \%$ and $23.5 \%$ and stood at near $47.1 \%$ and $28.8 \%$, which ratio remained before near 72.45 and $52.6 \%$.

\section{RESULT}

1. The marginal landholders of SC are near $76.11 \%$, which holds only $33.79 \%$ land area.

2. Marginal farmers of ST are near $49.08 \%$, which landholding area near $19.54 \%$.

3. The marginal farmers of general group ratio are $69.42 \%$, which operated area is near $19.54 \%$.

4. Overall, as per the census of $2001,63 \%$ households operating only 0 to 1 hect. Land means $80 \%$ people of SC ST and OBC operating only $20 \%$ land area. If $20 \%$ forward class operating $80 \%$ land area out of the total land in India.

5. The more population of SC and ST (Ratio) depends on traditional occupations. If compared to others, it constantly increased during the period of 1961 to 2011.but theirs house industries workers ratio is decreasing.

6. The poverty ratio of both classes has decreased only $20 \%$ in the overall period. And to eradicate all poverty it will take more periods something around 30 years. But, the government illustrates that the poverty ratio of this Class (SC, ST) has been eradicated, which is far from the fact.

7. Recently, the religions of India, failure to be established the social equality.

8. Today's after free India socio-economic Inequality is status as a person's social and economic position in relation to others, based on income, education and occupation.

\section{SUGGESTIONS}

- Need to generalization and free of the education sector for excluded groups.

- Since 1950, the fifth five-year plan was executed by planning commission, which provides the special action points of socio-economic development for SC and ST, on this guideline need to take quick action for the implement. But, in truly speaking, it is not happening due to lack of political desire

- There is urgent to suggest the measurements for SC and ST, to be less the dependence of economic means on others, as well as, the modern sources should be increased into secondary and territory sector in place of the traditional sources.

- The social disparities are created due to economic disparities, which are existing in Indian society, so to reduce that ,there should be executed the proper measurement by the government.

- The Constitution Act should have come into force to be executed the reservation of SC and ST in government institute as well as the Private sectors.

- The ceiling Act of land distribution should be revised by considering the family factors instead of the individual distribution. 


\section{CONCLUSION}

The caste system has mainly existed in India, Nepal, Pakistan and Shrilanka, which the part of South Asian countries in the world, as well as, it exists in Indonesia in South East Asia, and the China, Magnolia, Japan, Korea, North Korea, which situated in East Asia, Yemen in West Asia, West Africa, Mid-Africa which is part of Africa, if, its system has also existed in France and Spain in Europe Inland. Now caste annihilation, become above country, but today in India caste discrimination is strongly encouraged. The peoples of SC, ST, $\mathrm{OBC}$, NT and VJNT in India, are affected due to the existence of economic disparity, besides, are suffering from an immoral humiliation, however ,they don't irritate such like this trouble situation. Notwithstanding, the political and economic power have been centralized by the upper class, these disparities are the root cause of an injustice in India.

In overall, there is rise a question being observed the poor condition of mentioned people that, is the government doing the best try for living that in deprived condition?

Generally, various disorder creates due to class or caste system, of which, special rights and injustice disorder are specific, which are profitable for some groups and non-profitable for others, for instance, to acquire the special concession by rights is a first type disorder and, secondly, to use the authority for themselves an advantage in place of welfare of common people in society for their stability.

Mostly, some people in society can fulfil their livelihood with all leisure's, but other people are deprived of such like consumption due to lack of means.

The exclusion people's life can become a change by obtaining an equal opportunity in education, health and employment because these are the means of access in well-earned business as well as acquire to good knowledge of the economic transaction.

The people of India have been divided into upper and lower class due to social forms in society. To avoid this condition the economic forum will be changed, it means, is not sufficient to consider the social development in view of the mechanic method.

In recent times, also the SC and ST people are far from social and economic equality, including the NT, VJNT, and De-notified tribes that have been excluded from the main socio-economic stream. Due to such condition, there is no doubt that this event may lead the horrible revolution in India, now the social revolution will definitely happen to free from this social exclusion event. Dr. Ambedkar said, In India, the land holding matter is not only to be a livelihood, but it also regards to societal status, generally, which people have obtained some land that prestige rank will be at higher than that non-holder of land. Todays, the SC and ST peoples in the village cannot acquire a bit of land. Due to an acquisition act of land, it suggests that permanent rights of the land-holder to be acquired by land instead of only ownership of land for temporary basis, which rights should be reserved for the government to be decided the limitation of land for land-holder, but the government was failure to pass this act, consequently, the SC and ST People have not any solution to be acquired the land instead of encroachment.

\section{Acronyms \\ SC-Scheduled Caste \\ ST-Scheduled Tribe \\ OBC-Other Backward Class \\ NT-Nomadic Tribe \\ VJNT- (Vimukt Jati) De-Notified Nomadic Tribe}

\section{REFERENCE:}

[1] Action points for development of scheduled castes and scheduled tribes, Planning Commission govt. of India, New Delhi.

[2] Darshan Singh (2009) Development Of Scheduled Castes In India - A Review Journal of Rural Development, Vol. 28, No. (4), pp. 529 - 542, NIRD, Hyderabad.

[3] http://agcensus.dacnet.nic.in

[4] Indian Vision 2020 Report of the committee on India, Planning Commission GOI. Delhi.

[5] Karl Marx, Das Capital

[6] M.M. Thomas (2011), Salvation and Humanization, A crucial issue in the theology of mission for India, International review of mission vol-60, issue 237, Jan, 1971.

[7] Max Weber (1922), Economy and Society Publisher: University of California Press.

[8] Paul A. Samuelson (1997), Economics, Publisher: McGraw-Hill Education; 1 edition.

[9] Paulose Mar Paulose, Encounter in Humanization-Insights for Christian Marxist Dialogue and cooperation.

[10] Planning Commission, Eleventh Five Year Plan, 2007-2012, Volume I, Inclusive Growth and NSSO primary data 2009-10. 
[11] Primary Census Abstract for Total population, Scheduled Castes and Scheduled Tribes, 2011 Office of the Registrar General \& Census Commissioner, India.

[12] Ruth Levitas, Christina Pantazis, Eldin Fahmy, David Gordon, Eva Lloyd and Demi Patsios (2007), The Multi-Dimensional Analysis Of Social Exclusion.

[13] Sonalde Desai, Cecily Darden Adams, Amaresh Dubey (2008), Segmented Schooling: Inequalities in Primary Education, India Human Development Survey, Working Paper No. 6 